Jurnal Ilmu Keperawatan : Journal of Nursing Science 2020, Vol. 8, No. 2, 74-79

www.jik.ub.ac.id

Doi 10.21776/ub.jik.2020.008.02.2

P-ISSN: 2088-6012 E-ISSN: 2598-8492

\title{
RELATIONSHIP BETWEEN DURATION OF PLAYING ONLINE GAMES WITH EYE VISION IN SCHOOL AGE CHILDREN
}

Endah Marlinda ${ }^{1}$, Apolonia Antonilda Ina ${ }^{1}$, Eka Wahyuningrum $^{1 *}$

Afiliasi

1. Sekolah Tinggi Ilmu Kesehatan St. Elisabeth Semarang

Dikirim 9 April 2020

Direvisi 21 Agustus 2020

Diterima 31 Agustus 2020

Dipublikasikan 30 November 2020

*Corresponding author

Email:

ekawahyu877@gmail.com

\begin{abstract}
ABSTRAK
Gangguan penglihatan merupakan masalah kesehatan yang penting pada anak-anak karena 80\% informasi selama 12 tahun pertama kehidupan anak didapatkan melalui penglihatan. WHO mengatakan 2.,2 miliar penduduk dunia mengalami gangguan penglihatan. $22,1 \%$ total populasi penduduk Indonesia mengalami kelainan refraksi dan $15 \%$ diantaranya anak sekolah. Beberapa penelitian menyatakan faktor yang menyebabkan anak mengalami gangguan visus mata adalah bermain game online. Tujuan dari penelitian ini adalah untuk mengetahui hubungan durasi bermain game online dengan visus mata pada anak usia sekolah. Desain penelitian ini adalah cross sectional. Sampel dalam penelitian ini berjumlah 33 anak dengan menggunakan total sampling. Data durasi bermain game online diukur dengan lembar observasi dan visus mata diukur oleh refraksionis. Pengolahan data menggunakan uji fisher dan chi square dengan CI 95\%. Hasil penelitian menunjukkan sebanyak 39,4\% visus mata kanan responden tidak normal, dan sebanyak $57,6 \%$ visus mata kiri responden tidak normal. Durasi bermain game online lebih dari 2 jam sebanyak 36,4\%. Hasil uji statistik fisher $\mathrm{p}=0,719$ untuk mata kanan dan hasil uji statistik chi square $\mathrm{p}=0,162$ untuk mata kiri. Tidak ada hubungan yang signifikan antara durasi bermain game online dengan visus mata anak usia sekolah.
\end{abstract}

Kata kunci : Durasi Bermain Game Online, Visus Penglihatan, Anak Usia Sekolah

\begin{abstract}
Visual impairment is an important health problem in children because $80 \%$ of information during the first 12 years of a child's life is obtained through vision. WHO says 2.2 billion people suffer from visual impairment. 22.1\% of total population in Indonesia suffering abnormality refraction of which 15\% were school age children. The purpose of this research is to know the relationship between duration of playing online game with eye vision in school age children. The design of this research is cross sectional. Sample of this research is 33 children with total sampling method. The duration of playing online games measured by observation sheets and eye vision measured by refractionist. Processing data used fisher test and chi-square test with 95\% Confidence Interval (CI). The results showed that $39.4 \%$ of respondent's right eye vision was abnormal, 57.6\% of respondent's left eye vision was abnormal, and $36.4 \%$ respondent use game online more than 2 hours per day. Fisher's statistical test results $p=0.719(>0.05)$ and chi square statistical test results $p=0.162(>0.05)$. There is no relationship between the duration of playing online games with eye vision of school-age children.
\end{abstract}

Keyword : Duration of Playing Online Game, Eye Vision, School Age Children

Sitasi jurnal :

Marlinda E, Ina AA, Wahyuningrum E. 2020. Relationship Between Duration Of Playing Online Games With Eye Vision In School Age Children. Jurnal Ilmu Keperawatan 8 (2): 74-79 Doi: 10.21776/ub.jik.2020.008.02.2 


\section{PENDAHULUAN}

Visus adalah nilai kebalikan sudut (dalam menit) terkecil dimana sebuah benda masih dapat dilihat dan dibedakan. Visus atau ketajaman penglihatan digunakan untuk menentukan penggunaan kacamata dan memberi keterangan mengenai baik buruknya fungsi mata secara keseluruhan (Asriwati, 2017).

World Health Organisation (WHO)menyampaikan estimasi jumlah orang dengan gangguan penglihatan di seluruh dunia pada tahun 2010 adalah 285 juta orang atau $4,24 \%$ populasi, sebesar $0,58 \%$ atau 39 juta orang menderita kebutaan dan 3,65\% atau 246 juta orang mengalami low vision. Pada tahun 2019, WHO menyatakan 2,2 miliar penduduk dunia mengalami gangguan penglihatan. 1 miliar diantaranya memiliki gangguan penglihatan yang dapat di cegah. 312 juta anak (berusia kurang dari 19 tahun) mengalami myopia pada tahun 2015 (WHO, 2019).

Gangguan penglihatan dan kebutaan di Indonesia terus mengalami peningkatan dengan prevalensi 1,5\% dan tertinggi dibandingkan dengan angka kebutaan di negara-negara regional Asia Tenggara. Prevalensi kelainan refraksi adalah sebesar 22,1\% dari total populasi dan 15\% diantaranya diderita oleh anak sekolah(Pusat Komunikasi Publik Sekretariat Jendral Kementrian Kesehatan RI, 2012).

Gangguan penglihatan merupakan masalah kesehatan yang penting pada anak-anak karena $80 \%$ informasi selama 12 tahun pertama kehidupan anak didapatkan melalui penglihatan. Gangguan penglihatan pada anak berakibat buruk pada perkembangan anak, partisipasi dalam berkerjasama, produktivitas dan pencapaian prestasi akademik selain itu juga dapat menyebabkan harga diri yang rendah karena pandangan mereka yang berbeda dengan anak normal lainnya (WHO, 2019; Alvarez-peregrina et al., 2020).

Gangguan ketajaman penglihatan yang mayoritas dialami anak usia sekolah adalah ketajaman penglihatan yang rendah. Jenis kelamin, tipe sekolah, durasi paparan terhadap televisi, jarak dengan paparan televise, paparan perangkat mobiledan kunjungan untuk pemeriksaan mata berhubungan terhadap gangguan ketajaman mata anak usia sekolah (Bezabih, Abebe and Fite, 2017).

Penelitian oleh Rechichi (2017) menemukan asthenopia (seperti sakit kepala, eyelid tic, transient diplopia dan pusing) keabsenan stereopsis yang baik dan refraksi yang error lebih banyak pada anak yang menggunakan video game (Rechichi, De Mojà and Aragona, 2017). Penelitian ini mendukung Bener dan Al-Mahdi (2012) yang menemukan prevalensi ketajaman penglihatan rendah yang lebih banyak ditemukan pada pengguna internet dan televisi (Bener and Al-Mahdi, 2012).

Jumlah pengguna aktif internet di Indonesia sebanyak 150 juta jiwa atau sekitar 56\% dari total jumlah penduduk Indonesia pada awal tahun 2019. Sekitar 142,8 juta pengguna internet merupakan pengguna ponsel aktif. Empat puluh enam persen dari pengguna internet tersebut merupakan pengguna game online (Tomato Digital Indonesia, 2019).

Hasil penelitian sebelumnya oleh Oktavani dkk (2018) menunjukkan tidak terdapat hubungan antara intensitas penggunaan game online dengan visus mata pada siswa SMA. Penelitian oleh Sundari dkk (2015) menunjukkan terdapat hubungan antara durasi bermain game onlinedengan gangguan ketajaman penglihatan pada anak SMP (Oktavani and Fadilah, 2018; Sundari and Ratna, 2018).

Hasil studi pemetaan yang dilakukan oleh Tim Keperawatan Anak Stikes Santa Elisabeth tahun 2018 ditemukan 88,1\% anak mengalami gangguan ketajaman mata. Berdasarkan uraian di atas dan hasil beberapa penelitian sebelumnya peneliti tertarik untuk meneliti mengenai hubungan durasi bermain game online terhadap visus mata pada anak usia sekolah. Hasil penelitian ini dapat menjadi sumber rujukan dalam upaya promotif kesehatan mata anak usia sekolah.

\section{METODE}

Penelitian ini merupakan jenis penelitian kuantitatif dengan desain penelitian cross sectional. Penelitian ini dilakukan pada salah satu sekolah dasar (SD) swasta di Semarang pada bulan Agustus 2019. Pemilihan tempat berdasarkan studi pendahuluan sebelumnya ditempat tersebut yang menemukan sebagian besar anak mengalami gangguan visus mata. Teknik pengambilan sampel dalam penelitian ini adalah total sampling. Kriteria Inklusi yaitu responden yang berumur 6-12 tahun. Kriteria eksklusi yaitu orangtua siswa SD yang tidak bersedia anaknya 
menjadi responden, tidak bermain game online, siswa SD yang mengalami katarak kongenital, nistagmus, dan strabismus, siswa SD yang menggunakan kacamata. Penelitian ini diikuti oleh 33 siswa SD.

Pengumpulan data pada penelitian dilakukan dengan memberikan lembar angket mengenai durasi bermain game online dan mengukur visus mata dengan kartu snellen. Pengukuran visus mata dilakukan oleh refraksionis. Refrasionis tersebut telah lulus dari pendidikan refraksi optisi dibuktikan dengan ijazah, dan memiliki surat tanda registrasi refraksionis. Lembar angket durasi bermain game online digunakan untuk mengetahui rata-rata anak bermain game online selama satu hari didapatkan menggunakan metode recall 7 hari.

Penelitian ini dimulai dengan membagikan informed consent kepada orangtua anak. Penelitian ini melibatkan 5 orang asisten peneiti dan satu orang refraksionis optisi. Anak dibagikan lembar angket durasi bermain game online, setelah terisi anak diukur visus matanya. Pengolahan data menggunakan uji fisher dan chi square untuk mengetahui hubungan durasi bermain game online dengan visus mata anak usia sekolah.

\section{HASIL}

Karakteristikrespondenyang mengikutipenelitian ini dan hasil analisa data digambarkan dalam tabel di bawah ini.

Tabel 1: Data Karakteristik Responden

\begin{tabular}{lcc}
\hline \multicolumn{1}{c}{ Karakteristik } & $\mathrm{n}$ & $\%$ \\
\hline Usia & & \\
6 tahun & 2 & 6,1 \\
7 tahun & 6 & 18,2 \\
8 tahun & 7 & 21,2 \\
9 tahun & 4 & 12,1 \\
10 tahun & 5 & 15,2 \\
11 tahun & 5 & 15,2 \\
12 tahun & 4 & 12.1 \\
\hline Jenis Kelamin & & \\
Laki-laki & 25 & 75,8 \\
Perempuan & 8 & 24,2 \\
\hline Jenis alat untuk bermain & & \\
Handphone (hp) & 31 & 93,9 \\
$\quad$ komputer & 2 & 6,1 \\
\hline
\end{tabular}

\begin{tabular}{lcc}
\hline Dimensi game online & & \\
2 dimensi & 8 & 24,2 \\
3 dimensi & 23 & 69,7 \\
& 2 & 6,1 \\
$2+3$ dimensi & & \\
\hline Lama bermain game online & & \\
& 3 & 9,1 \\
$<1$ tahun & 18 & 54,5 \\
1 tahun & 9 & 27,3 \\
2 tahun & 1 & 3 \\
3 tahun & 2 & 6,1 \\
$\quad 4$ tahun & & \\
\hline Durasi bermain game & & \\
online & 21 & 63,6 \\
$\quad \leqslant 2$ jam & 12 & 36,4 \\
$\quad>2$ jam & & \\
\hline Visus mata kanan & 20 & 60,6 \\
$\quad$ Normal & 13 & 39,4 \\
$\quad$ Tidak normal & 14 & 42,4 \\
\hline Visus mata kiri & 19 & 57,6 \\
$\quad$ Normal & & \\
Tidak normal & & \\
\hline
\end{tabular}

Sumber : data primer yang diolah tahun 2020

Berdasarkan data tersebut sebagian besar usia responden 8 tahun 7 anak yang bermain game online (21,2\%), jenis kelamin laki-laki 25 anak (75,8\%), alat untuk bermain game online menggunakan hp 31 anak $(93,9 \%)$, dimensi game online yang dimainkan terbanyak adalah 3 dimensi 23 anak (69,7\%), dan lama bermain 1 tahun sebanyak 18 anak (54,5\%). Anak yang bermain game online dengan durasi lebih dari 2 jam 12 anak $(36,4 \%)$, visus mata kanan tidak normal 13 anak $(39,4 \%)$ dan visus mata kiri tidak normal 19 anak $(57,6 \%)$.

Tabel 2: Hubungan durasi game online dengan visus mata kanan anak usia sekolah

\begin{tabular}{|c|c|c|c|c|}
\hline & & Normal & $\begin{array}{c}\text { Tidak } \\
\text { normal }\end{array}$ & $p$ \\
\hline Durasi & $\leqslant 2 \mathrm{jam}$ & 12 & 9 & 0,719 \\
\hline $\begin{array}{l}\text { bermain } \\
\text { game online }\end{array}$ & >2jam & 8 & 4 & \\
\hline Total & & 20 & 13 & \\
\hline
\end{tabular}

Uji fisher

Sumber : Data primer yang diolah tahun 2020

Tabel 2 menunjukkan 23 (39,4\%) mata kanan anak mempunyai visus mata tidak normal. Tabel 2 juga 
menunjukkan hubungan antara durasi bermain game online dengan visus mata kanan anak usia sekolah. Hasil uji statistik ini didapatkan nilai pvalue sebesar 0,719 yang berarti tidak ada hubungan yang signifikan antara durasi bermain game online dengan visus mata kanan anak usia sekolah.

Tabel 3: Hubungan durasi game online dengan visus mata kiri anak usia sekolah

\begin{tabular}{|c|c|c|c|c|c|c|}
\hline & & \multicolumn{4}{|c|}{ Visus mata kiri } & \multirow[t]{3}{*}{$p$} \\
\hline & & \multicolumn{2}{|c|}{ Normal } & \multicolumn{2}{|c|}{$\begin{array}{c}\text { Tidak } \\
\text { normal }\end{array}$} & \\
\hline & & $\mathrm{n}$ & $\%$ & $\mathrm{n}$ & $\%$ & \\
\hline $\begin{array}{l}\text { Durasi } \\
\text { bermain }\end{array}$ & $\leqslant 2 j a m$ & 7 & $21,2 \%$ & 14 & $42,4 \%$ & 0,162 \\
\hline $\begin{array}{l}\text { game } \\
\text { online }\end{array}$ & >2jam & 7 & $21,2 \%$ & 5 & $15,2 \%$ & \\
\hline Total & & 14 & $42,4 \%$ & 29 & $57,6 \%$ & \\
\hline
\end{tabular}

Uji chi-square

Sumber : Data primer yang diolah tahun 2020

Tabel 3 menunjukkan 31 (57,6\%) mata kiri anak mempunyai visus mata tidak normal. Tabel 3 juga menunjukkan menunjukkan hubungan antara durasi bermain game online dengan visus mata kiri anak usia sekolah. Hasil uji statistik ini didapatkan nilai pvalue sebesar 0,162 yang berarti tidak ada hubungan yang signifikan antara durasi bermain game online dengan visus mata kiri anak usia sekolah.

\section{PEMBAHASAN}

Hasil dari penelitian ini menunjukkan tidak ada hubungan yang signifikan antara durasi bermain game online dengan visus mata anak usia sekolah. Hasil uji statistik ini didapatkan nilai $\mathrm{p}$ value $>0,05$ sehingga $\mathrm{H} 0$ diterima dan $\mathrm{H} 1$ ditolak.

Penelitian ini sejalan dengan penelitian yang dilakukan Yoki Oktavani tahun 2018 bahwa tidak ada hubungan antara intensitas penggunaan game online dengan visus pada siswa di SMA. Intensitas penggunan game online yang dimaksud penelitian sebelumnya adalah intensitas yang menggunakan tingkatan level seperti rendah, sedang, dan tinggi. Penelitian Anisa Suangga tahun 2012 mendapatkan hasil serupa dimana tidak terdapat hubungan yang signifikan antara aktivitas bermain video game dengan school myopia. (Suangga, Ropi and Mardiyah, 2011; Oktavani and Fadilah, 2018)
Tidak terdapatnya hubungan durasi bermain game online dengan visus mata anak usia sekolah pada penelitian ini disebabkan oleh faktor lain. Faktor lain yang mempengaruhi visus mata dan tidak dikendalikan dalam penelitian ini antara lain asupan nutrisi atau vitamin A, gangguan mata lain yang tidak teridentifikasi (astigmatisme, amblyopia), faktor genetic dan screen based activity anak selain game online.

World Health Organization (WHO) dalam world report on vision menyatakan kekurangan vitamin A pada anak menyebabkan malnutrisi kronik pada anak dan dapat menyebabkan corneal opacity (WHO, 2019). Faktor lain yang dapat menyebabkan penurunan visus mata adalah gangguan penglihatan yang tidak teridentifikasi. Gangguan mata yang tidak teridentifikasi seperti astigmatisme atau lengkung kornea yang tidak rata dapat menyebabkan penurunan visus mata karena cahaya dibiaskan secara tidak rata. Amblyopia juga merupakan gangguan mata yang tidak teridentifikasi yang dapat menurunkan visus mata pada anak akibat mata dan otak tidak bekerja sama dengan benar (Terri K, 2019).

Faktor genetik keluarga juga dapat menurunkan gen mata minus sehingga visus mata menurun. Beberapa orang responden memiliki orangtua yang memakai kacamata, tetapi tidak teridentifikasi apakah orangtua responden tersebut memakai kacamata karena faktor usia atau memang murni ada gangguan pada mata sehingga dapat menurunkan gen gangguan mata ke anak. Faktor genetik merupakan irregular penetration atau penetrasi tidak beraturan sehingga dapat diturunkan pada tingkat 1 yaitu ayah dan ibu ke anak, dapat diturunkan pada tingkat 2 yaitu kakek nenek dan seterusnya. Faktor genetik keluarga berperan sekitar 30-35\% (Uprety et al., 2016; WHO, 2019).

Aktivitas lain yang mempengaruhi visus mata adalah screen based activity atau aktivitas di depan layar kaca. Anak-anak selain memainkan game online juga menonton televisi dengan durasi antara 1-2 jam dan 3-4 jam. Terdapat anak yang bermain game online tetapi juga menonton televisi, ada juga yang tidak bermain game online tetapi menonton televisi lebih dari 2 jam per hari sehingga jika diakumulasi aktivitas di depan layar kaca termasuk game online maupun tanpa game online mencapai lebih dari 2 jam. Rekomendasi durasi penggunaan media berbasis layar untuk anak 
menurut AAP adalah tidak lebih dari 1 sampai 2 jam per hari (American Academy of Pediatrics and WHO, 2019).

Aktivitas melihat dekat dan lama juga dapat mempengaruhi penglihatan. Aktivitas melihat dekat dan lama selain dari screen based activites juga bisa dari aktivitas responden ketika membaca atau belajar. Jarak pandang yang kurang dari standar ukur dalam waktu yang lama dapat menimbulkan kelelahan mata (astenopia) seperti mata merah, mata pegal, mata berair, mata pedih dan penglihatan kabur. Sistem penglihatan akan berupaya berlebih untuk memperoleh ketajaman penglihatan dalam waktu yang lama dan jarak yang terlalu dekat. Akibatnya kemampuan akomodasi akan berkurang dan mengakibatkan terjadinya gangguan ketajaman penglihatan. Jarak pandang mata dengan buku yang ideal adalah 25-30 cm (Juneti, Bebasari and Nukman, 2015).

Hasil penelitian menunjukkan dengan durasi bermain game online lebih dari 2 jam dengan visus mata kanan normal terdapat sebanyak 8 orang responden, dan untuk visus kiri normal sebanyak 7 orang responden. Salah satu faktor yang dapat mempengaruhi tetap normalnya mata adalah waktu jeda saat bermain game online. Mata dianjurkan untuk mengalihkan pandangan setiap 15 menit sekali. Mengalihkan mata 15 menit sekali dapat menjaga kelenturan otot mata sehingga ketajaman penglihatan tetap terjaga (Harvard Health Letter, 2017).

Nutrisi (Vitamin E, beta-carotene, vitamin C, zinc and cooper) dan antioksidan juga berpengaruh dalam kesehatan mata. Beta-carotene merupakan komponen mayor dari pigmen macula. Nutrisi tersebut berperan penting melindungi retina dan melalui kandungan antioksidan mampu melakukan fungsi sebagai filter terhadap blue light. Blue light juga dihasilkan oleh game online. Sinar ultraviolet (UV) dapat merusak lensa mata dan blue light yang dihasilkan HP dan komputer dapat merusak retina. Antioksidan dapat menetralkan efek kerusakan mata dari sinar-sinar tersebut yang dapat mencegah kerusakan lipid, protein, dan komponen lensa lainnya (Lawrenson and Downie, 2019; Puckett and Ruby, 2019). Peneliti tidak dapat mengontrol nutrisi dan antioksidan yang dikonsumsi oleh responden sehingga hal-hal tersebut dapat menyebabkan visus mata yang tetap normal walaupun responden bermain game online lebih dari 2 jam.

Dalam penelitian ini seluruh responden yang mengalami anisometropia berbedaannya adalah kurang dari 1,5 D sehingga kedua mata masih dapat digunakan secara bersama-sama dengan baik bahkan ada yang tidak menyadari bahwa dirinya mengalami gangguan tajam penglihatan. Kondisi dimana terdapat perbedaan refraksi pada kedua mata disebut anisometropia. Anisometropia dibagi menjadi beberapa tingkatan yaitu perbedaan refraksi antara kedua mata kurang dari 1,5 dioptri (D) dimana kedua mata masih dapat digunakan bersama-sama dengan fungsi yang baik, perbedaan refraksi antara kedua mata 1,5 D sampai 3 D dan perbedaan refraksi lebih dari 3 D. Penyebab anisometropia adalah karena pemanjangan bola mata yang berbeda antara kiri dan kanan selama masa pertumbuhan. Menurut penelitian Li Deng tahun 2012 prevalensi anisometropia meningkat dari usia 5 sampai 15 tahun. Anisometropia tumbuh menyertai hipermetropi dan miopia. (Deng and Gwiazda, 2012; Basyir S, Arintawati and Saktini, 2016)

\section{KESIMPULAN}

Hasil penelitian menunjukkan tidak terdapat hubungan yang signifikan antara durasi bermain game online dengan visus mata anak usia sekolah.Tenaga kesehatan disarankan meningkatkan upaya deteksi dini terhadap visus mata anak untuk mengoptimalkan fungsi penglihatan pada 12 tahun kehidupan pertama anak. Penelitian selanjutnya sebaiknya meneliti mengenai faktor-faktor yang mempengaruhi visus mata anak usia sekolah. Peneliti merekomendasikan untuk penelitian yang akan datang meneliti tentang faktor - faktor yang memengaruhi visus mata anak usia sekolah. 


\section{DAFTAR PUSTAKA}

Alvarez-peregrina, C. et al. (2020) 'Visual Health and Academic Performance in School-Aged Children', International Journal of Environmental Research and Public Health, 17(7), pp. 1-8. doi: 10.3390/ ijerph17072346.

AmericanAcademy of PediatricsandWHO(2019) Screen Time Guidelines by Age. Available at: https:// www.eyepromise.com/wp-content/uploads/ 2019/05/Screentime-Recommendation-ChartFinal_AAP-WHO.pdf.

Asriwati (2017) Fisika Kesehatan dalam Keperawatan. 1st edn. Yogyakarta: CV Budi Utama. Available at: https://books.google.co.id.

Basyir S, I., Arintawati, P. and Saktini, F. (2016) ‘Perbedaan Penglihatan Stereoskopis Pada Penderita Anisometropia Ringan-Sedang Dan Berat', Jurnal Kedokteran Diponegoro, 5(4), pp. 1092-1100.

Bener, A. and Al-Mahdi, H. S. (2012) 'Internet use and television viewing in children and its association with vision loss: A major public health problem', Journal of Public Health in Africa, 3(1), pp. 6569. doi: 10.4081/jphia.2012.e16.

Bezabih, L., Abebe, T.W. and Fite, R. O. (2017) 'Prevalence and factors associated with childhood visual impairment in Ethiopia', Clinical Ophthalmology, 11, pp. 1941-1948. doi: 10.2147/OPTH.S135011.

Deng, L. and Gwiazda, J. E. (2012) 'Anisometropia in children from infancy to 15 years', Investigative Ophthalmology and Visual Science, 53(7), pp. 3782-3787. doi: 10.1167/iovs.11-8727.

Harvard Health Letter (2017) Electronic screen alert: Avoid this vision risk; Looking at a screen too long may lead to computer vision syndrome, Harvard Medical School. Available at: https://www. health.harvard.edu/diseases-and-conditions/ electronic-screen-alert-avoid-this-vision-risk.

Juneti, Bebasari, E. and Nukman, E. (2015) 'Gangguan tajam penglihatan pada anak sekolah dasar kelas V dan kelas VI di SDN 017 Bukit Raya Pekanbaru tahun 2014', JOM, II(2), pp. 1-10. Available at: scholar.google.co.id.

Lawrenson, J. G. and Downie, L. E. (2019) 'Nutrition and Eye health', Nutrients, 11(9), pp.11-14. doi: 10.3390/nu11092123.
Oktavani, Y. and Fadilah, T. F. (2018) 'Hubungan intensitas penggunaan game online dengan visus mata pada siswa SMA', Jurnal Biomedika dan Kesehatan, 1(3), pp. 198-202. doi: 10.18051/ jbiomedkes.2018.v1.198-202.

Puckett, T. and Ruby, E. (2019) Esports players need to manage eye strain, blue light exposure. Available at: https://globalsportmatters.com/ health/2019/09/25/esports-players-needto-manage-eye-strain-blue-light-exposure/ (Accessed: 9 April 2020).

Pusat Komunikasi Publik Sekretariat Jendral Kementrian Kesehatan RI (2012) Mata Sehat di Segala Usia untuk Peningkatan Kualitas Hidup Masyarakat Indonesia. Available at: https:// www.kemkes.go.id/article/view/2082/matasehat-di-segala-usia-untuk-peningkatankualitas-hidup-masyarakat-indonesia.html (Accessed: 30 May 2019).

Rechichi, C., De Mojà, G. and Aragona, P. (2017) 'Video game vision syndrome: A new clinical picture in children?', Journal of Pediatric Ophthalmology and Strabismus, 54(6), pp. 346-355. doi: 10.3928/01913913-20170510-01.

Suangga, A., Ropi, H. and Mardiyah, A. (2011) 'Hubungan Aktivitas Bermain Video Game Dengan School Myopia Pada Siswa-Siswi Sd Asy Syifa 1 Bandung', Majalah Keperawatan Unpad, 13(2), pp. 1-15

Sundari and Ratna, L. P. (2018) 'Hubungan antara durasi bermain game online dengan gangguan tajam penglihatan pada anak sekolah menengah pertama (SMP) di kota Denpasar', E-Jurnal Medika, 7(8), pp. 1-12. Available at: https://ojs. unud.ac.id.

Terri K (2019) Buku ajar keperawatan pediatri volume 1. Edisi 2. Jakarta: Penerbit buku kedokteran EGC.

Tomato Digital Indonesia (2019) Data Digital Indonesia 2019. Available at: http://tomato.co.id/datadigital-indonesia-2019/.

Uprety, S. et al. (2016) 'Profile of paediatric low vision population: A retrospective study from Nepal', Clinical and Experimental Optometry, 99(1), pp. 61-65. doi: 10.1111/cxo.12314.

WHO (2019) World report on vision, World health Organisation. World Health Organization. 